\title{
Mapping of Hydrothermal Minerals Related to Geothermal Activities Using Remote Sensing and GIS: Case Study of Paka Volcano in Kenyan Rift Valley
}

\author{
Joline Achieng1, Joseph Mutua², Geoffrey Mibei², L. Olaka1', Aaron K. Waswa' ${ }^{1}$ \\ ${ }^{1}$ Department of Geology, University of Nairobi, Nairobi, Kenya \\ ${ }^{2}$ Geothermal Development Company, Nairobi, Kenya \\ Email: jolieachieng@gmail.com
}

How to cite this paper: Achieng, J., Mutua, J., Mibei, G., Olaka, L. and Waswa, A.K. (2017) Mapping of Hydrothermal Minerals Related to Geothermal Activities Using Remote Sensing and GIS: Case Study of Paka Volcano in Kenyan Rift Valley. International Journal of Geosciences, 8, 711-725.

https://doi.org/10.4236/ijg.2017.85039

Received: April 12, 2017

Accepted: May 24, 2017

Published: May 27, 2017

Copyright $\odot 2017$ by authors and Scientific Research Publishing Inc. This work is licensed under the Creative Commons Attribution International License (CC BY 4.0).

http://creativecommons.org/licenses/by/4.0/

(c) (i) Open Access

\begin{abstract}
Remote sensing investigations combined with Geographical investigation systems (GIS) provide a rapid and cost-effective method for prospecting hydrothermal and geothermal systems. Most geothermal systems in Kenya are found in remote areas where accessibility is difficult. This study was carried out on Paka volcano which is located in the Kenyan rift valley. The aim of the study was to use remote sensing and GIS to investigate hydrothermal minerals and structures associated with geothermal activities. The study involves use of Landsat TM image classification using ENVI 5.1 and ArcGIS. Lineament extraction was done using PCI geomatics 2015 while Rose diagrams were generated using Rockworks 16. The research has shown that lithological, hydrothermal mineralization and structural maps can be generated form Landsat TM images using remote sensing and GIS. It has been shown that faults trend in the Northeast, North and Northwest direction. Hydrothermal minerals that are rich in iron and clays occur on Paka volcano mountain and its neighbouring areas.
\end{abstract}

\section{Keywords}

Hydrothermal Minerals, Remote Sensing and GIS, Geothermal Resources, Kenyan Rift

\section{Introduction}

The effects of climate change and unpredictable weather patterns have affected hydro-power generation in Kenya. This has influenced the strategies in the power sector towards stimulating growth and development of geothermal ener- 
gy. Geothermal exploration in Kenya started in the 1960s with the drilling of two geothermal wells in Olkaria [1]. The aim of geothermal surface exploration is to determine the resource characteristics of the geothermal system before drilling is done. The common scientific approaches involved are geology, geochemistry, and geophysics which are very costly. This research shows how remote sensing images can be used to map hydrothermal minerals and entire geology during reconnaissance or the detailed mapping of an area to lower the cost of geothermal exploration [2]. Areas that are remote, inaccessible, or with very rugged terrains can be explored using remote sensing technique. The application of remote sensing to geothermal exploration relies on spatial and spectral properties of airborne and space-borne remote sensing platforms [3]. Recently, there have been significant improvements in the quality of remotely sensed images (wavelength coverage and spectral resolution). Geothermal mineral indicators include: hydrothermal alteration (clays and sulfates), sinter, tufa (carbonates) and thermal anomalies [4].

The presence, abundance and stability of hydrothermal alteration minerals depend on lithology, pressure, temperature, permeability and fluid composition of the system. Through the study of alteration minerals, estimate of subsurface temperature and any changes can be deduced [5]. There are scarce clay geothermometry studies of low-temperature hydrothermal conditions. The low temperature clays represent the surficial evidence of deeper and hidden hightemperature zones, therefore they are useful as guides for prospecting [6].

Paka is one of the geothermal prospects in the Kenyan Rift. It is defined by a shield volcano, and is characterized by intense and widespread geothermal surface activity manifested in the form of fumaroles, hot grounds and hydrothermally altered rocks. Over the last two decades, detailed geological geothermal investigations have become less visibly considered in exploration of geothermal resources, due to budgetary constraints; yet there is high demand for energy for the Republic of Kenya. There is need to evaluate this problem by coming up with other ways which are cost effective for doing geothermal exploration. Most equipment for geothermal exploration can be quite expensive; for instance geophysical equipment are very costly as compared to remote sensing softwares. Some areas are also insecure and inaccessible. Therefore there is need to use a method of geothermal exploration; which will cater for these problems.

This project aims at mapping lithology, structurers, and characterizing clays of Paka volcano in the Kenyan Great Rift Valley. Identifying and interpreting hydrothermal minerals (clays) is useful in surface geothermal exploration. Clays related to surface geothermal activity act as mineral geothermometers and guide in pointing out the best drilling targets by indicating possible up flow and outflow zones. Information about clay minerals also helps in defining the hydrology of a geothermal reservoir. The existence of structures plays an important role in creating a flow path through which hydrothermal fluids are transported to the surface; hence the need to map them. The eruption centres are useful, in that they indicate the magma chamber below the system is still active. By using tech- 
niques of remote sensing; volcanic activity, geological formations and alteration mineral zones can be detected and mapped on a regional scale. The use of remote sensing is accurate and it covers a large area at once. It is also cost-effective, in terms of spatial resolution.

\section{Geographic Setting}

The Paka volcano is in Rift valley (Figure 1), located $25 \mathrm{~km}$ north of Lake Baringo. It is bound by the Latitude $00^{\circ} 55^{\prime} \mathrm{N}$ and Longitude $36^{\circ} 12^{\prime} \mathrm{E}$ and rises to an altitude of $1697 \mathrm{~m}$. Paka Volcano lies in the inner trough of the Kenya Rift. The volcano massif extends over an area of about $280 \mathrm{~km}^{2}$ and rises between $600-$ $700 \mathrm{~m}$ above the rift floor. The central volcano (Paka) rising to a height of $1697 \mathrm{~m}$, is surrounded by plains to the north, south, west and east (Figure 2). At the summit, the well preserved caldera is about $1.5 \mathrm{~km}$ in diameter, and is filled with young basaltic flows. Several craters dotting the massif are aligned in a NNE direction. The volcano is cut on its central and eastern flanks by a swarm of NNE trending faults. The surface is rocky and rugged, covered by low cover of bush and shrubs.

\section{Geological Setting}

Paka is composed of trachytic and basaltic lavas and pyroclastic deposits. The

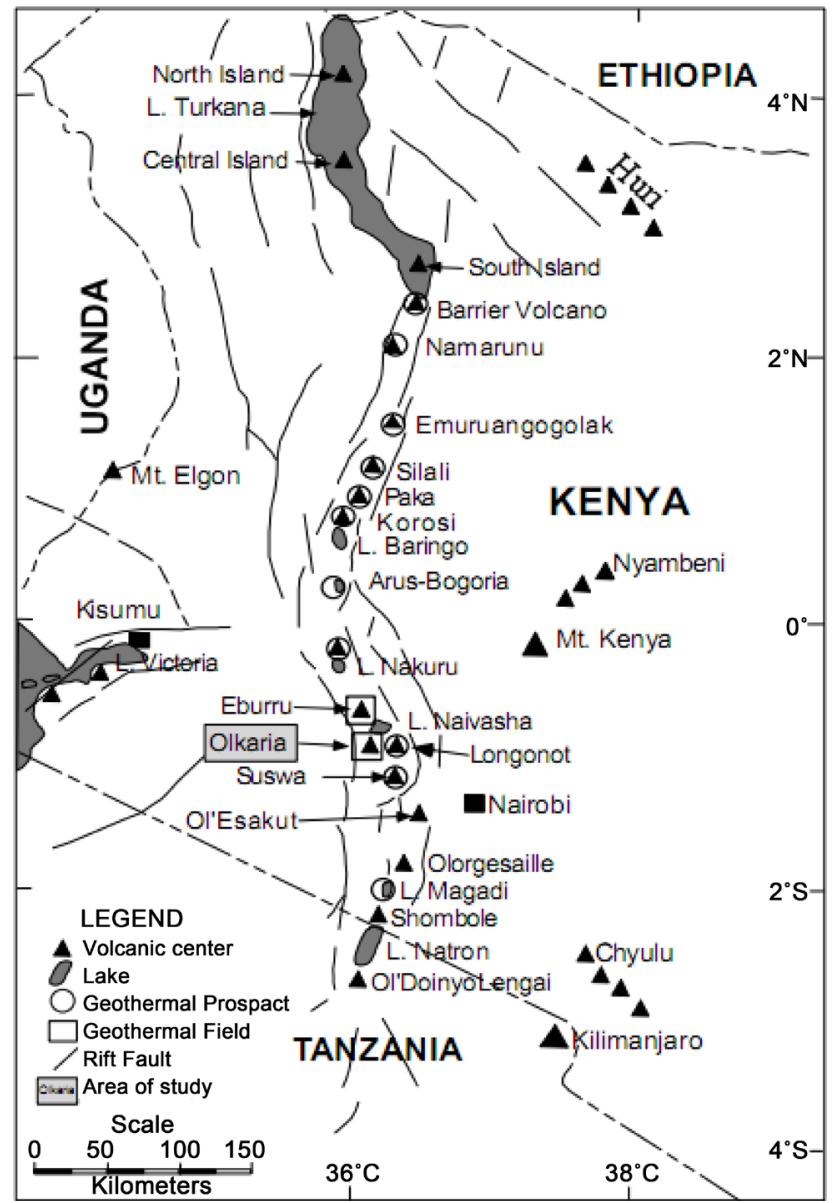

Figure 1. Geographic location of Paka Volcano within the Kenyan Rift [7]. 

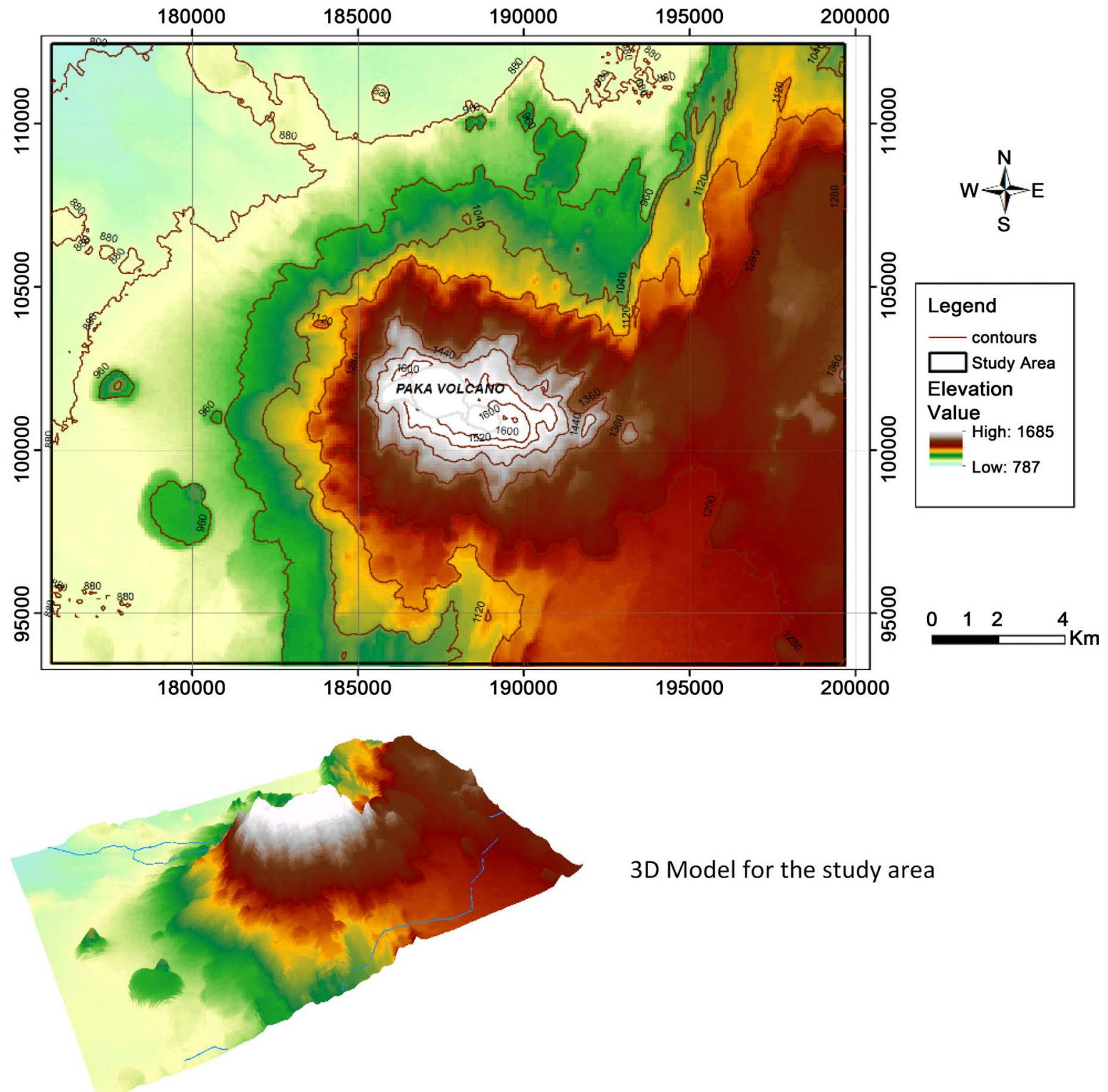

Figure 2. The Elevation of Paka Volcano Mountain in the Kenya rift valley generated by ArcGIS 10.1.

geology of Paka seems to be highly influenced by tectonism and volcanism. The evolutionary history may be broadly divided into two periods of Trachytic volcanism separated by basaltic activity and faulting. Volcanic activity commenced by $390 \mathrm{Ma}$ and has continued to within $10 \mathrm{Ma}$. Much of the shields forming lavas are covered by trachytic pyroclastic deposits which are seen to cover the areas around the volcano.

\section{Geothermal Manifestation of Paka Volcano}

Surface geothermal activity is manifested in form of hot ground, steaming ground and fumaroles. Geothermal activity covers an area of approximately 32 $\mathrm{km}^{2}$; extending northwards across the summit area and down the northern flanks of the volcano. Geothermal activity within the main zone is mostly controlled by faults which trend NNE, associated with pumice cones and scoria 


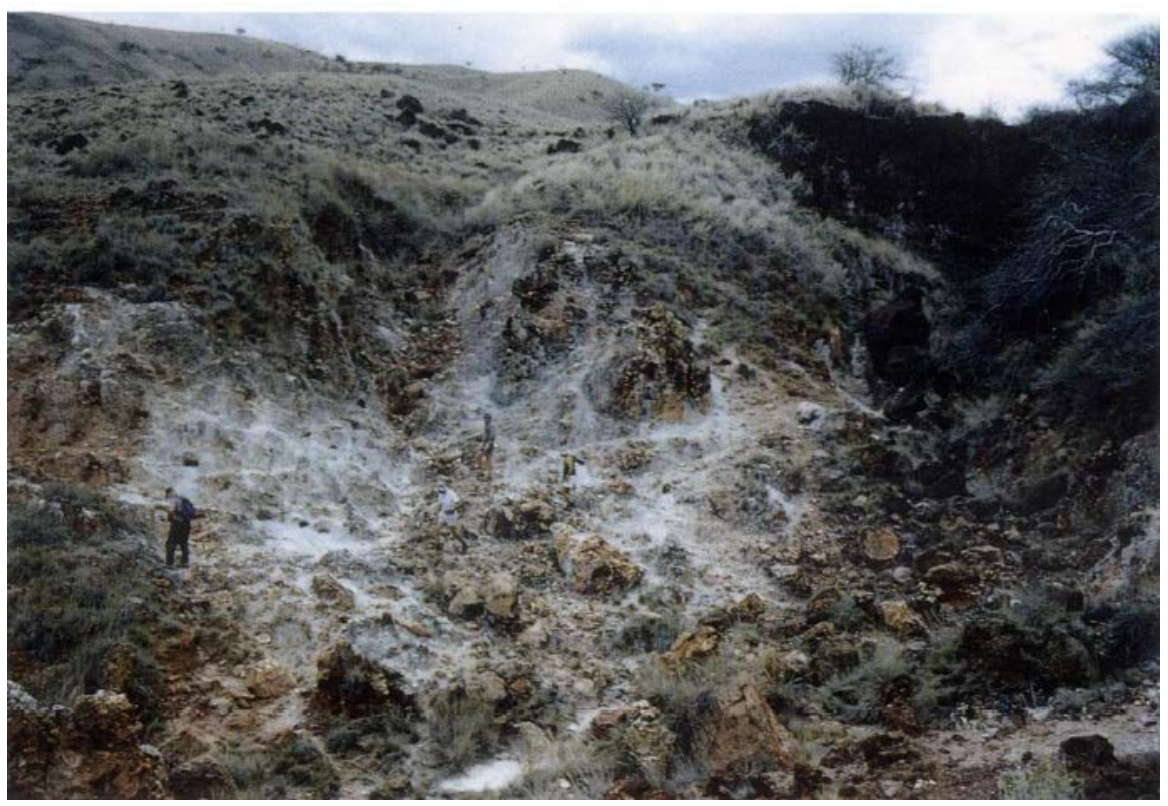

Figure 3. Northern flanks of Paka showing areas of hydrothermal alteration and volcanic activity in pumice deposits [8].

aligned along the fractures. Highest temperatures are found within areas of steaming ground, evidenced by red, purple and white clays. Areas of geothermal extinction (Figure 3 ) are indicated by hydrothermally altered grounds [8].

The hottest ground and strongest fumaroles are found at the caldera, on the south western rim of the cone. Basalt and scoria have been altered to purple, red and white clays with sulfates. At the base of the caldera, trachyte have been altered to kaolinite and alunite (white clays). At the southern flanks, pyroclastics have been altered to red clays and lower temperatures are noted. There are no hot springs in Paka. There are pools of warm water which form within the craters by condensation from fumaroles on almost-vertical rock surfaces.

\section{Materials and Methods}

After acquiring Landsat 7 ETM satellite image and the DEM from the internet, these data sets were processed using the necessary softwares (ENVI 5.1 and Arc GIS 10.3). A lithological map, structural map and hydrothermal alteration maps were developed. These three maps are important geological data sets in evaluating a geothermal resource.

\subsection{Lithology Mapping}

The methods performed in this study employed the image processing and analyzing geospatial imagery techniques provided by software ENVI 5.1 to carry out the lithological classification on Landsat TM image of the study area. The methodology consisted of three steps which are pre-processing, lithological classification, and post-processing. Maximum Likelihood classification was chosen to perform the supervised classification. Landsat TM satellite data was downloaded from http://earthexplorer.usgs.gov/acquired on10-Feb-2014. The bands used for 
the composites were band 7, band 4 and band 1 in Red, Green and Blue channels respectively in ENVI software. The training sites were developed after running unsupervised classification to assess the suitable classification algorithm and optimal number of classes. Supervised image classification was conducted using maximum likelihood classifier. Sieving and clumping of the resulting classes was carried out for the vectorized classification derivatives. The final lithological map was developed using ArcGIS 10.1.

\subsection{Geological Structures and Eruption Centers}

Knowlegde based feature extraction method was used to digitize structures and eruption centres from the image composite. The data preparation was done in Envi 5.1 where Landsat TM (Bd 7/R, Bd 4/G, Bd 1/B) composite was developed and exported to ArcGIS 10.1 software. To facilitate identification of the structures and eruption centers, the composite image was draped over a digital elevation model to contrast the structures and eruption centers from other features. The structures and the eruption centers were digitized.

Landsat 7 ETM image and DEM were obtained. Band combinations were done in ENVI. The faults and eruption centres were overlayed with DEM and digitized in Arc GIS. A structure (fault) map with eruption centres was developed.

\subsection{Clays (Hydrothermal Alteration Zones)}

The spectral bands of Landsat TM are well-suited for recognizing assemblages of alteration minerals. Recognition of hydrothermally altered rocks that may be associated with mineral deposits can thus be identified and mapped. There are numerous methods that can be used to map alteration using remotely sensed data. In this study, band ratio method was used. Band ratio method is the very simple and powerful technique in the remote sensing. Basic idea of this technique is to emphasize or exaggerate the anomaly of the target object. Each object has its own spectral reflectance pattern indifferent wavelength portion. Spectral reflectance curve is a kind of fingerprint of the object. The object or rock unit may have high reflectance value in some spectral portion, however, it may absorb in another spectral region.

The reflectance spectra of the common hydrothermal clay minerals; Alunite, illite, kaolinite, and montmorillonite have distinctive absorption reflectance minima at wavelengths within the bandpass of Landsat TM band 7 as shown in Figure 4. The alteration minerals have higher reflectance values within Landsat TM band 5. Ratio images can emphasize and quantify these spectral differences. A TM image consists of picture elements-pixels that represent a ground resolution cell of 30 by $30 \mathrm{~m}$. For each pixel the reflectance values for all bands are recorded as digital numbers on an eight-bit scale from 0 to 255. Ratio images are prepared by dividing the value for one band by that of another band, after atmospheric corrections have been made. [9] explains how TM ratio 5/7 distinguishes altered rocks containing clays and alunite from unaltered rocks. Both 


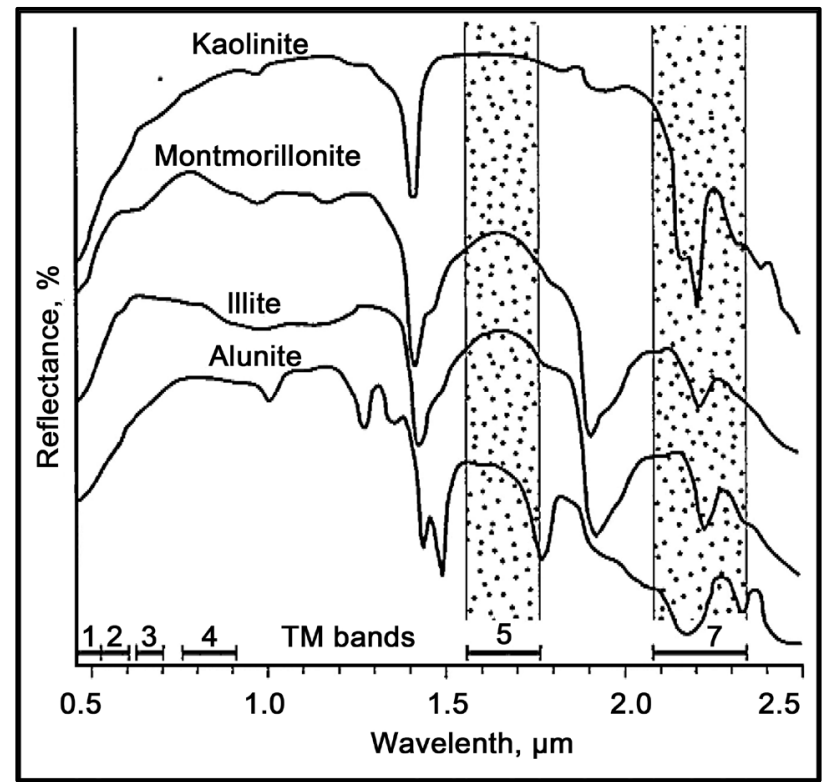

Figure 4. Laboratory reflectance spectra of common hydrothermal minerals [9].

rocks have similar values in band 5 . The reflectance of unaltered rocks in band 7 is similar to that in band 5 . Therefore, the $5 / 7$ ratio for unaltered rocks is unity 1.00. Altered rocks, however, have lower reflectance in band 7 because of the absorption caused by the minerals shown in Figure 4 above. Therefore, the 5/7 ratio for altered rocks is much greater than unity.

\subsection{Iron Minerals on $3 / 1$ Ratio Images}

Iron oxides and sulfates are the second group of minerals associated with hydrothermally altered rocks. The spectra of the iron minerals have low blue reflectance in Landsat TM band 1 and high red reflectance in Landsat TM band 3. Iron-stained hydrothermally altered rocks therefore have high values in a $3 / 1$ ratio image.

\subsection{Color Composite Ratio Images}

Color composite ratio images were produced by combining three ratio images in blue, green, and red. Figure 5 shows ratios 3/5,3/1, and 5/7 in red, green, and blue, respectively. The orange and yellow hues delineate the outer and inner areas of altered rocks in a pattern similar to that of the density sliced ratio images. An advantage of the color ratio image is that it combines the distribution patterns of both iron minerals and hydrothermal clays. A disadvantage is that the color patterns are not as distinct as in the individual density-sliced images.

Generally the following steps were followed in carrying out the band ratio analysis of alteration minerals:

1) Converting the Landsat TM data to surface reflectance data using dark object subtraction atmospheric correction algorithm in Envi 5.1;

2) Carrying out the band ratios (5/7,3/1 and $3 / 5$ respectively) and computing statistics of the results; 


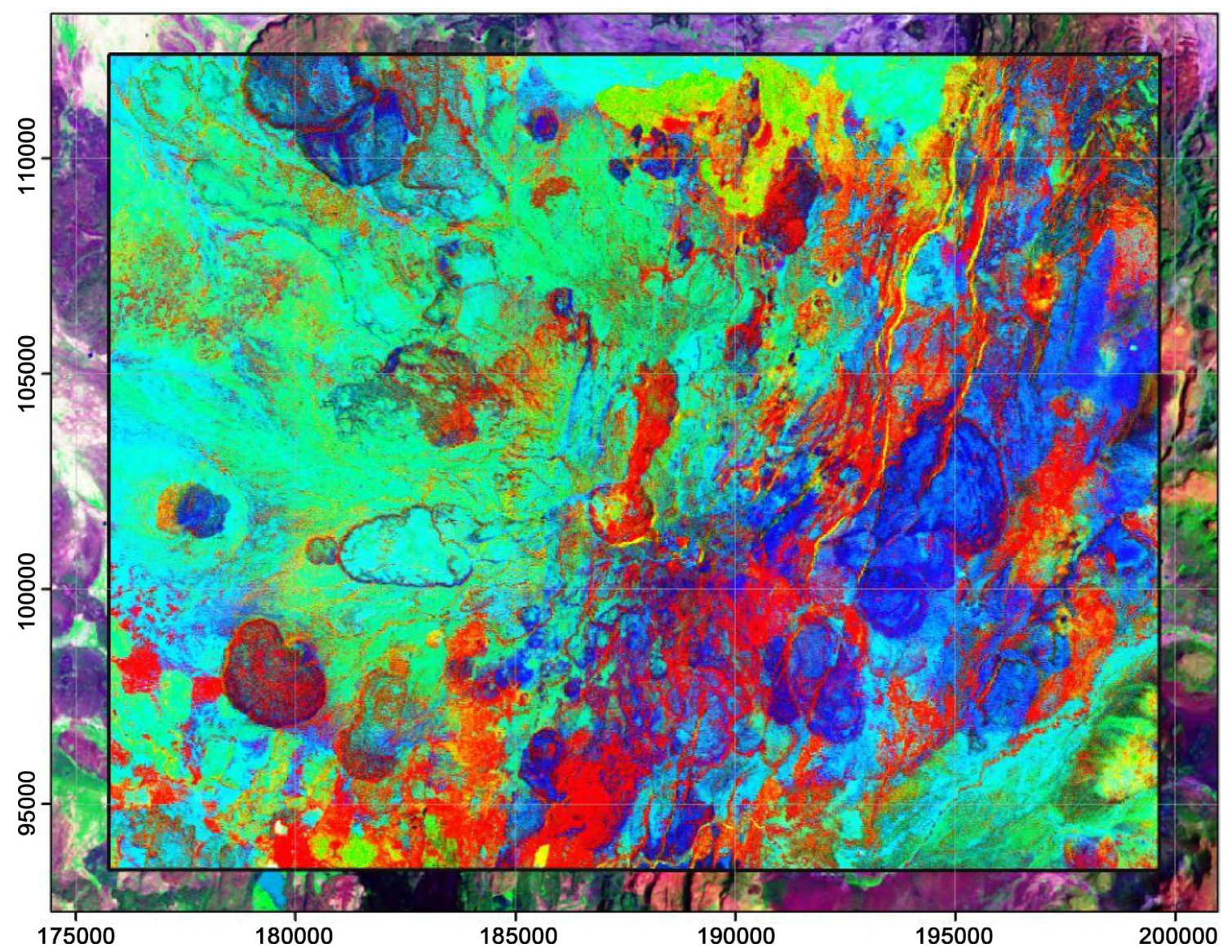

Figure 5. Image of the colour composite ratio images.

3) Resampling of the results of the band rations to 8 bit prior to density slicing and extraction of alteration mineral spectra and anomalous areas;

4) Preparation of the final anomaly maps in ArcGIS 10.1.

\section{Results and Discussion}

In Paka the main lithology are lavas and alluvium. The lavas mainly include trachyte and basalts. These shows that the rocks are bimodal in nature such that we have the basic rocks represented by basalts at one end and acidic rocks represented by trachyte at one end. This indicates a very dynamic magmatism where differentiation has occurred in magma chamber and new rejection of magma as inferred by the basalts. Other magmatic activity is represented by volcaniclastics. This means that actually a magma chamber exists below Paka, where differentiation occurs at top of the chamber represented by gases and more sillic material erupted at the volcaniclastic. The presence of magma chamber is an indication that a heat source is present that drives the geothermal system under Paka volcano.

Alluvium on the other hand is a factor of topography and erosion where low lying areas usually transected by flood waters are where these deposits are found. The geological structures are well defined by The DEM image and previous maps. Structures are important in geothermal system as fluid flow conduits, 
mainly hot water and steam. Usually down flow and up flow structures occur for recharge and conduit for a geothermal system respectively. The up flow structures are usually targeted for drilling in Paka geothermal manifestations occur along mapped structures.

Hydrothermal alteration are usually mapped by observation in the field, they are as indicators of geothermal system. They also infer structural trends. The important hydrothermal alterations are the clay alteration.

\subsection{Lithology}

The following lithological map was obtained in Arc GIS after performing unsupervised and supervised image classification in ENVI 5.1

The lithology of Paka consists of mostly trachytes and basalt rocks, with volcanic flows and few mugearites as shown from remote sensing technique (Figure 6). The lavas are bimodal and occur at and around the volcanic center where magma chamber below is inferred. The trachyte and volcaniclastic are particularly important since they infer differentiation hence magma chamber and therefore heat source for a geothermal system.

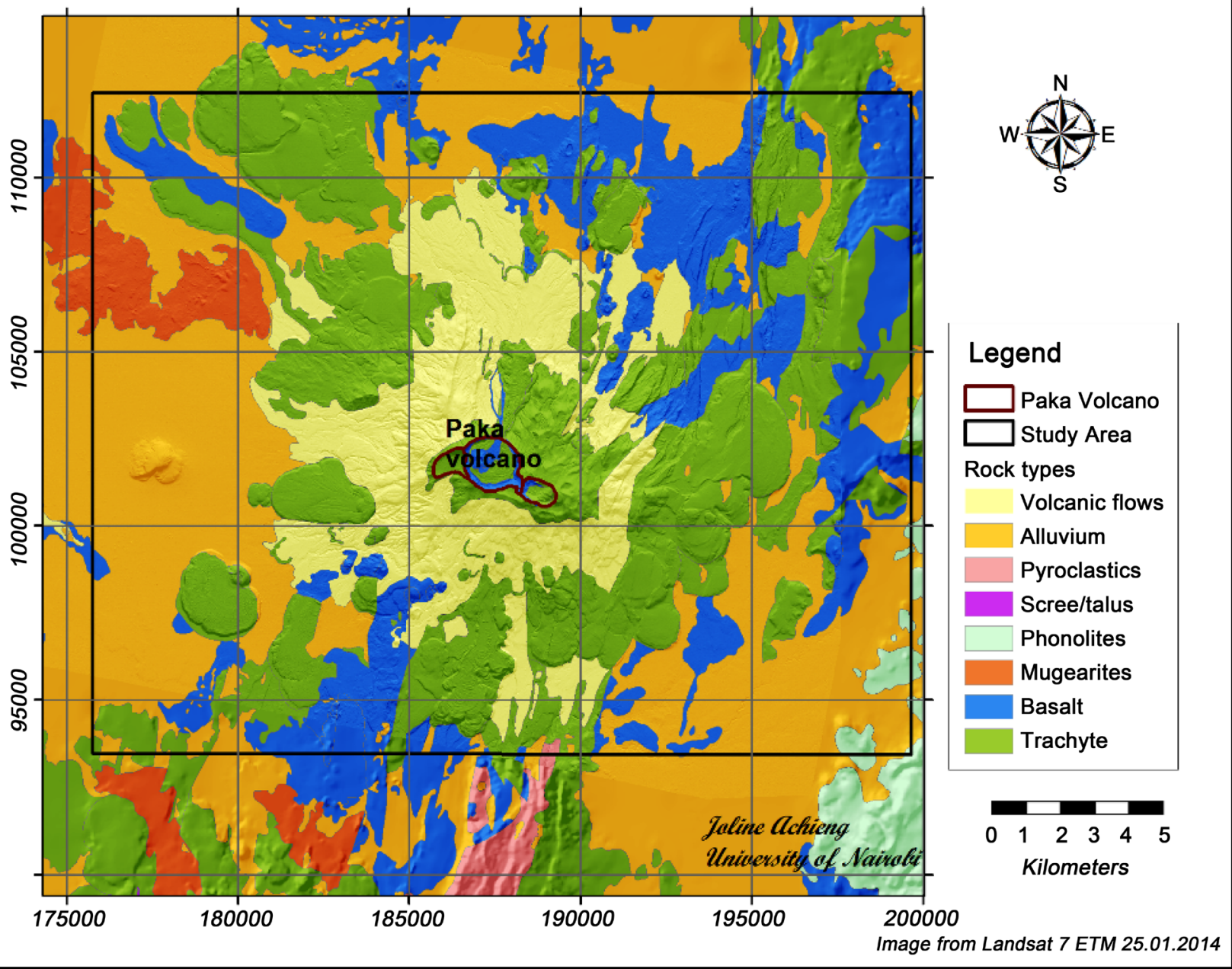

Figure 6. Map showing the lithology of Paka volcanic site. 


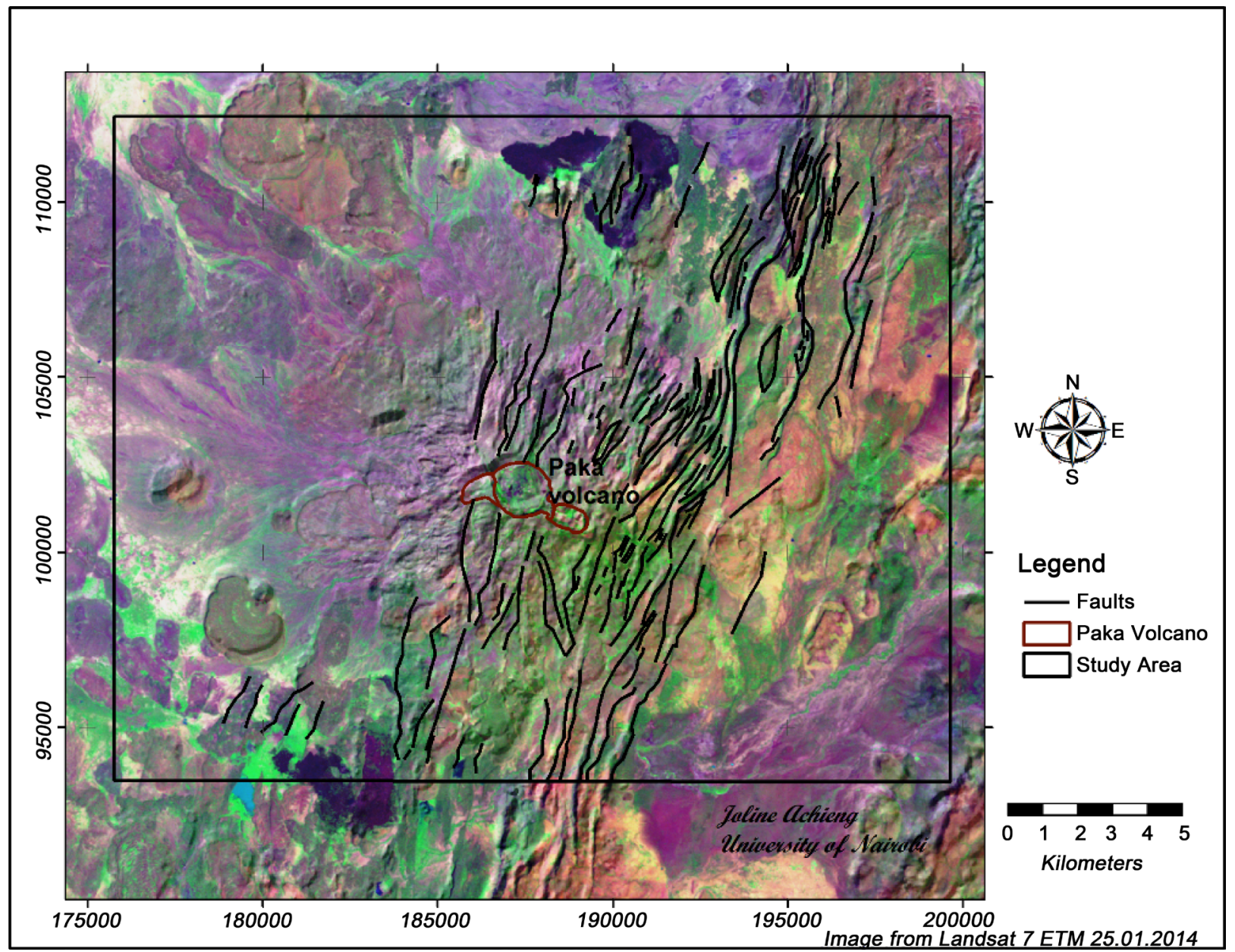

Figure 7. Map of faultsin Paka volcanic site.

\subsection{Structures and Eruption Centres}

The structures identified in Paka volcano are mainly faults (Figure 7). These were obtained from digitizing landsat image overlayed with DEM in Arc GIS and the following map was developed.

The structures that were identifiable from the landsat images were faults. This was possible by the aid of elements of visual interpretation. The shadow effect enabled digitization of these faults. Most of the lineaments trend in the North Eas, Northt and North West direction as shown rose diagram (Figure 8).

Most; if not all structures, are aligned in N-S orientation (Figure 8), this is consistent with the main rift faults as stress regime of the rift break up. Most of the structures show fumaroles indication area of leakages of the geothermal system. Other structures are open and are recharge areas.

Eruption centres are points of lava outflow (Figure 9). They indicate areas of active volcanic activity. They also show high temperatures in the area. The alignments are indicative of structural trends consistent of the rift.

Combined map of eruption centres and structural map (Figure 10) elucidate more of the relationship of tectonics and volcanism in the area. The orientation of eruption centers and faults coincide (Figure 11). 
Most faults occur in basalts and trachyte rocks. The faults trend in the NE to NNE direction.

\subsection{Hydrothermal Alterations}

Hydrothermally altered zones are indicated by the blue and red colours. These areas are mainly along the fault zones. This shows that hydrothermal alterations (clays); which are geothermal manifestations are mainly structure controlled. The areas in red represent iron minerals which are heavy, they are weathered and eroded materials deposited in erosional channels or low-lying area where alluvium are also deposited.

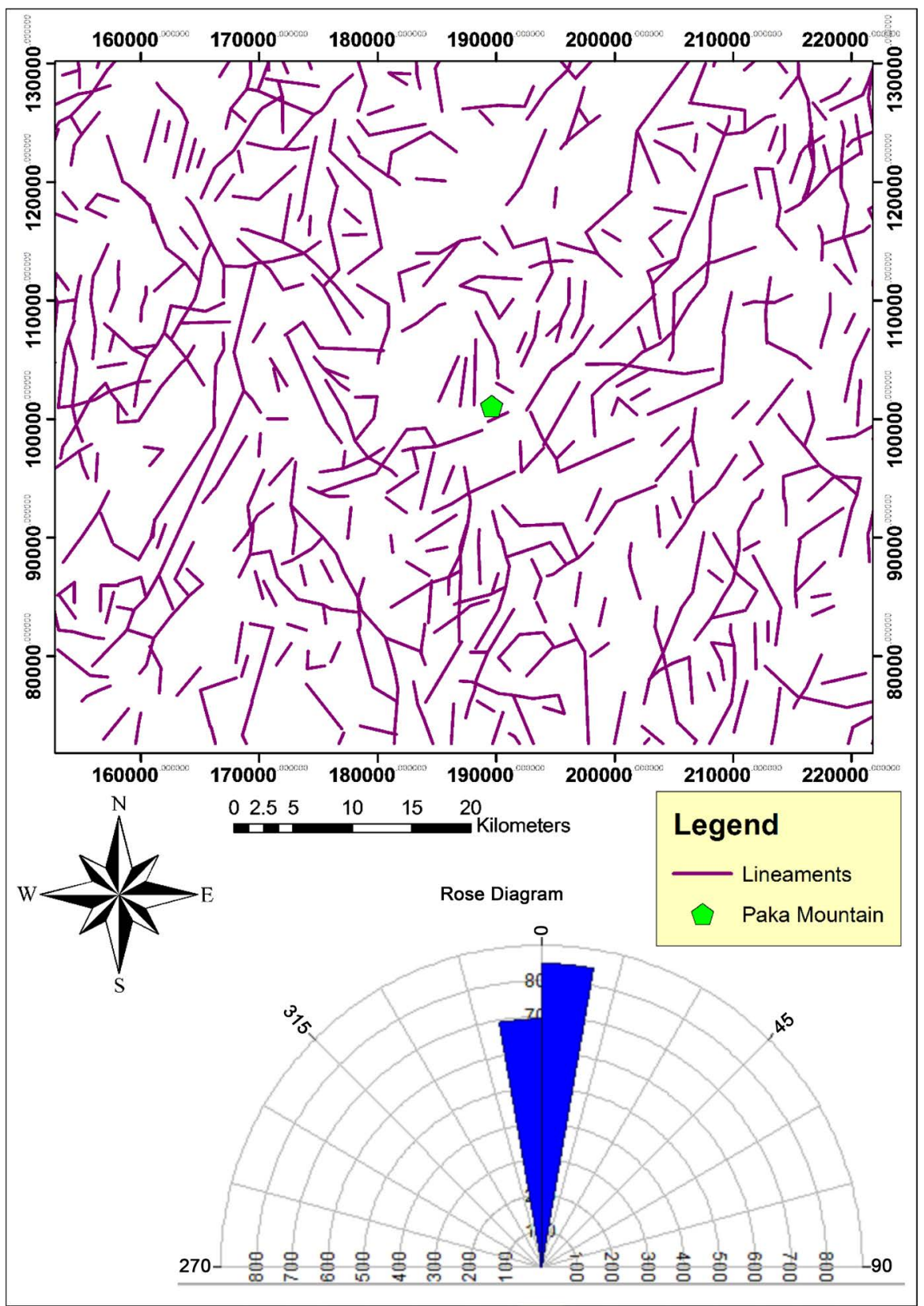

Figure 8. A map and a rose diagram showing lineament trend of Paka volcano and its neighbouring areas. 


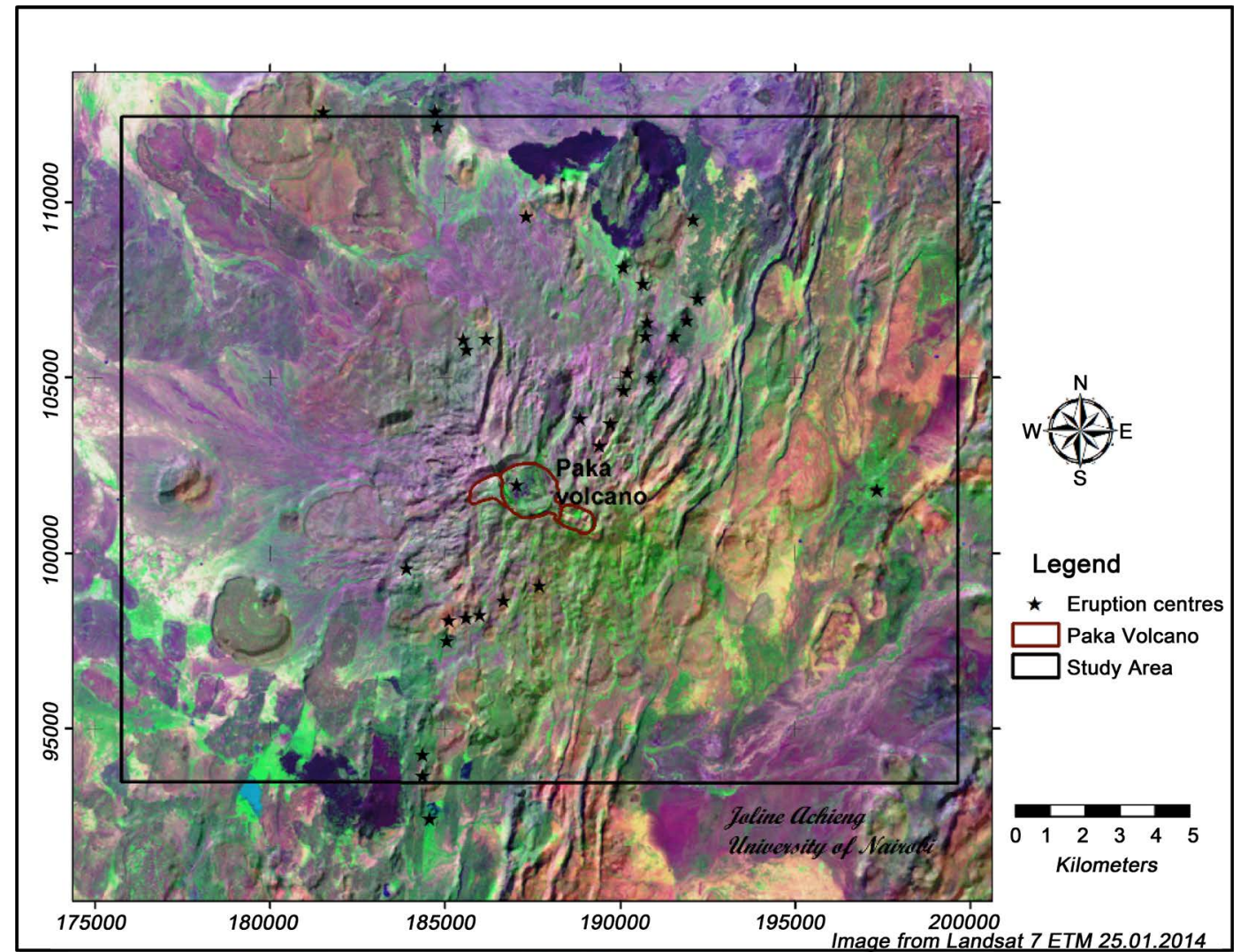

Figure 9. Map of eruption centres in Paka volcanic site.

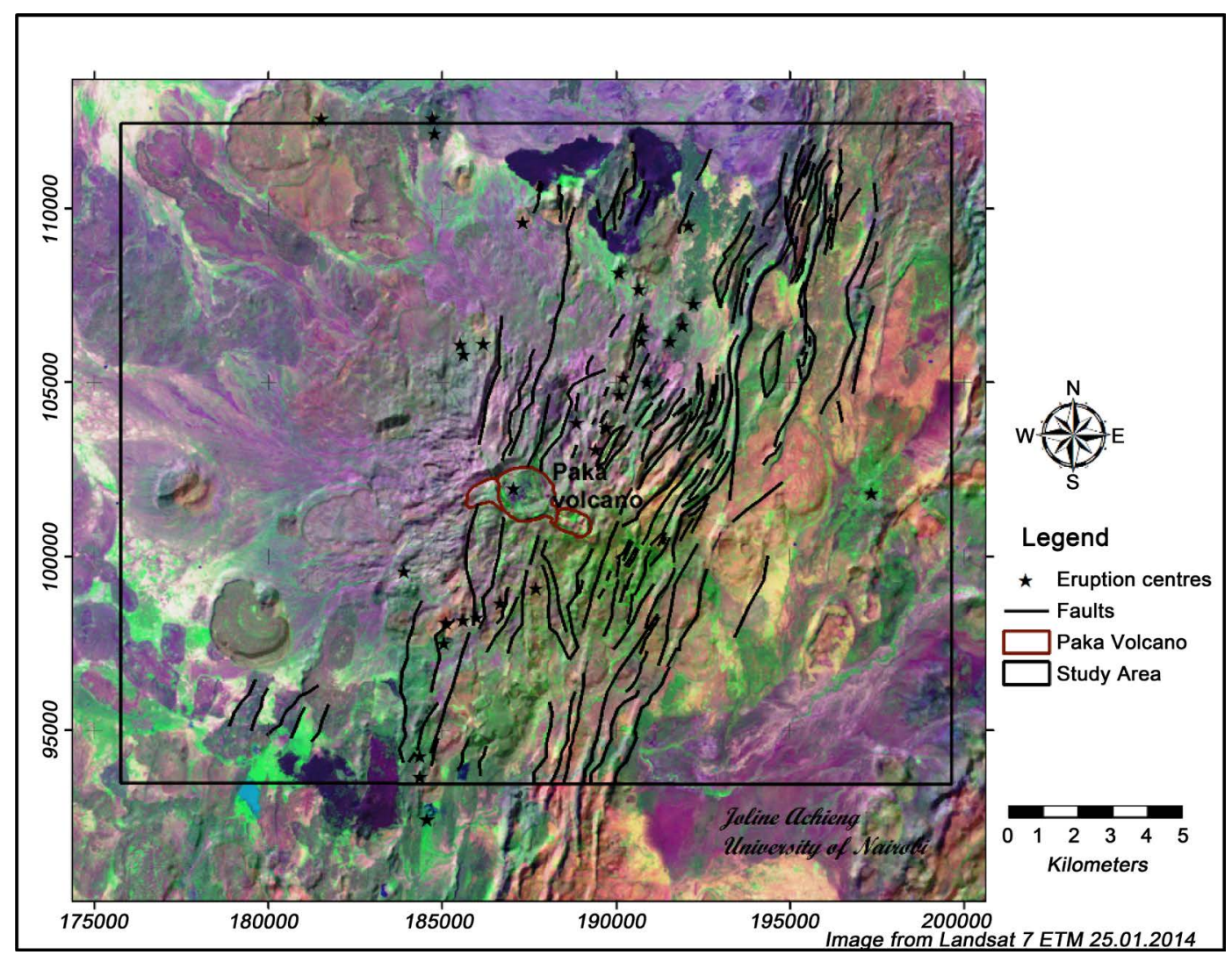

Figure 10. Faults and eruption centres. 


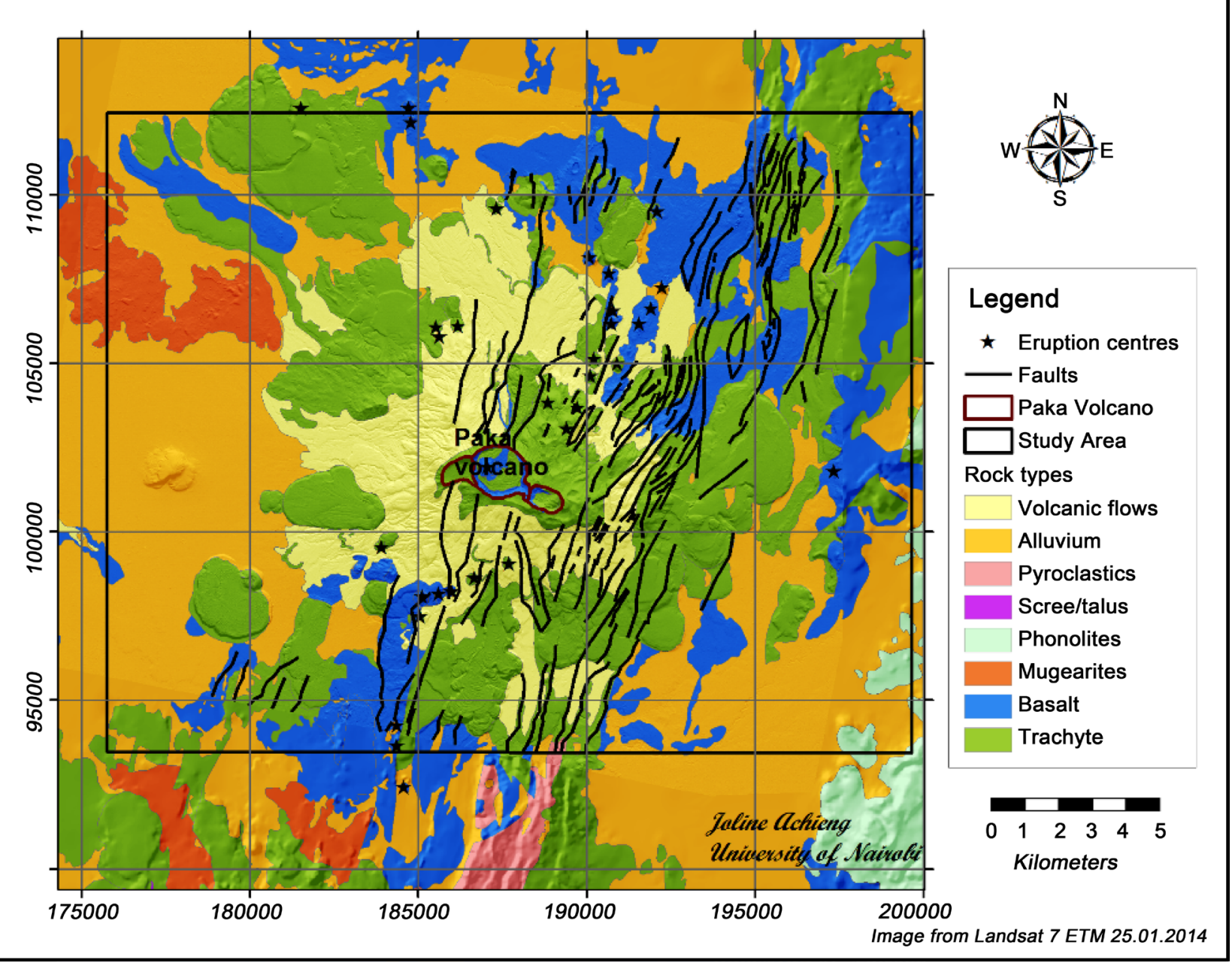

Figure 11. Map showing lithology, faults and eruption centres in Paka volcanic site.

\subsection{Clays and Iron Minerals}

The clay minerals occur along fault zones, which represent leakages areas and are good indicators of presence of a geothermal system in Paka volcano (Figure 12).

\section{Conclusion}

This study aimed to use the ability of remote sensing techniques to locate hydrothermal minerals and geological structures. The study site was selected in the rift valley where most of the geothermal centers exist. The area covered was about 2400 square kilometers. The achievement of the goal of the application of remote sensing techniques on studied Paka volcano led to the realization of different lithologies around Paka Mountain. Hydrothermal minerals (Sericite and Kaolinite) on Paka volcano were also detected by Landsat TM. Hydrothermal minerals (Sericite and Kaolinite) are observed along the faults. The association of the fault and hydrothermal minerals indicates that the fluids that caused mineralization were generated through the faults. Mineralization might have taken place due to geothermal activities on the Mountain. Structural lineaments (faults and fractures) around the volcano trend in the North-South direction. Rose 


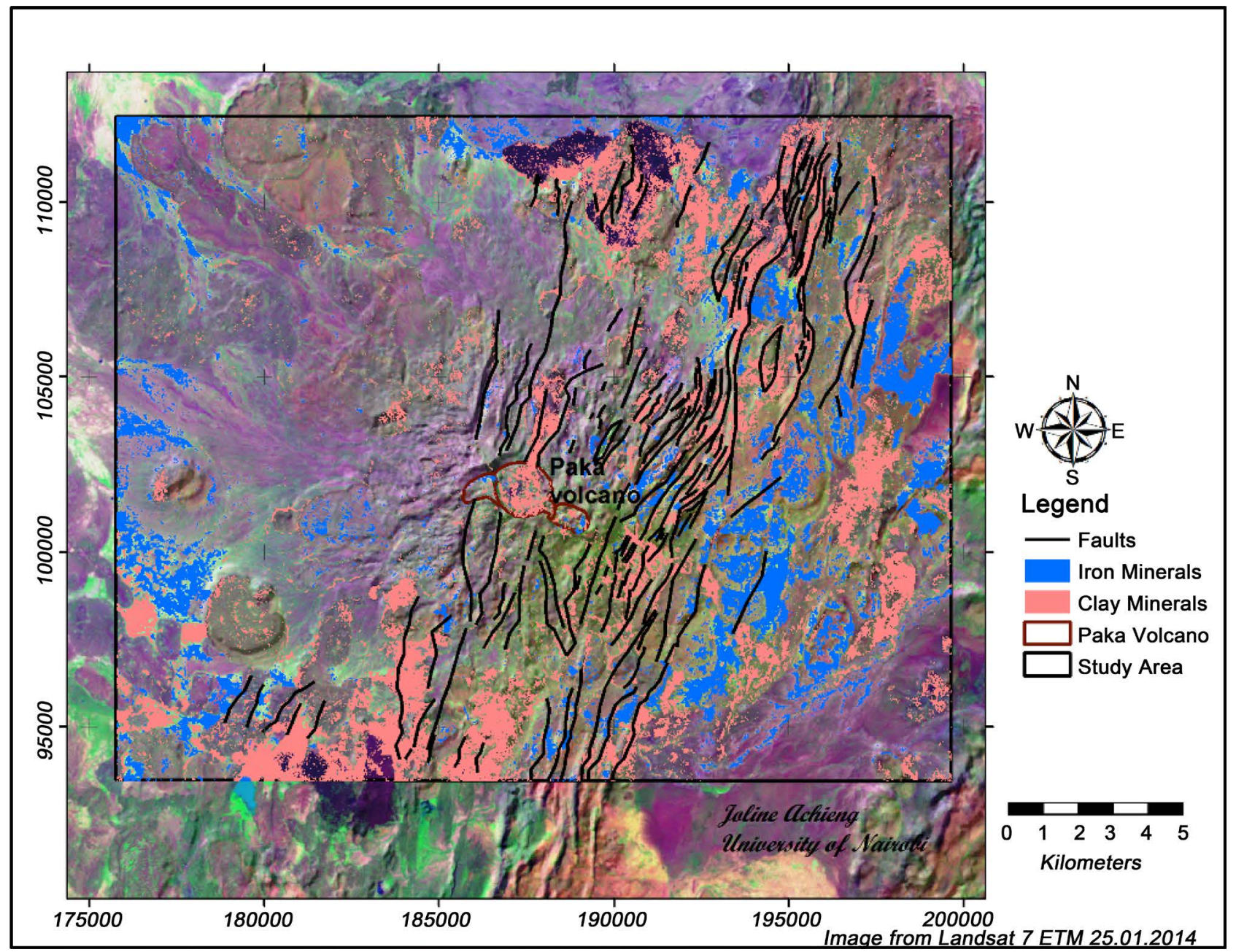

Figure 12. Map showing faults, iron andclay minerals (hydrothermal alteration zones) in Paka volcanic site.

diagram shows that most of the lineament trend in the Northeast, North and Northwest. These lineaments are mainly the faults which seem to follow the trend of the major Kenya rift valley that trends in the North-South direction.

\section{References}

[1] Omenda, P.A. (1994) Geological Control on the Reservoir Characteristics of Olkaria West Geothermal Field, Kenya. Proceedings of the 19th Workshop on Geothermal Reservoir Engineering, Stanford, 18-20 January 1994, 125-129.

[2] Waswa, A.K, Nyamai, C.M, Mathu, M,M and Ichang'i, D.W (2015) Intergration of Geological Mapping and Remote Sensed Studies for the Discovery of Iron Ore Mineralization in Mutomo-Ikutha Area, SE Kenya. Universal Journal of Geosciences, 3, 39-50. https://doi.org/10.13189/ujg.2015.030201

[3] Ochieng, L. (2013) Overview of Geothermal Surface Exploration Methods. Geothermal Development Company, Nakuru Kenya.

[4] Calvin, W.M., Coolbaugh, M., Kratt, C., and Vaughan, R.G. (2005) Application of Remote Sensing Technology to Geothermal Exploration. In Rhoden, H.N., Steininger, R.C., and Vikre, P.G., Eds., Geological Society of Nevada Symposium 2005: Window to the World, Reno, Nevada, 1083-1089.

[5] Harvey, C.C., Gunderson, R., and Cumming, W (2000) Methylene Blue Adsorption: 
a Real Time Rig Geologist Tool for Estimating Geothermal Reservoir Temperatures and Forecasting Drillhole Stability Problems. Proceedings of the New Zealand Geothermal Workshop, Auckland, November 2000, 151-155.

[6] Ghazban, F. (2004) Alteration and Geochemistry of Mount Taftan Geothermal Prospect South eastern Iran. Iranian International Journal of Science, 5, 43-62.

[7] Wamalwa, R.N., Waswa, A.K., Nyamai, C.N., Mulwa, J. and Ambusso, W.J. (2016) Evaluation of the Factors Controlling Concentration of Non-Condensable Gases and Their Possible Impact on the Performance of Geothermal Systems: Case Study of Olkaria Wells in the Kenyan Rift Valley. International Journal of Geosciences, 7, 257-279. https://doi.org/10.4236/ijg.2016.73021

[8] Dunkley, P.N., Smith, M, Allen, D.J. and Darling, W.G. (1993) The Geothermal Activity and Geology of the Northern Sector of the Kenya Rift Valley. British Geological survey Research Report SC/93/1.

[9] Sabins, F.F., (1997) Remote Sensing-Principles and Interpretation. 3rd Edition, W.H. Freeman, New York, NY.

\section{Scientific Research Publishing}

\section{Submit or recommend next manuscript to SCIRP and we will provide best} service for you:

Accepting pre-submission inquiries through Email, Facebook, LinkedIn, Twitter, etc. A wide selection of journals (inclusive of 9 subjects, more than 200 journals) Providing 24-hour high-quality service User-friendly online submission system Fair and swift peer-review system Efficient typesetting and proofreading procedure Display of the result of downloads and visits, as well as the number of cited articles Maximum dissemination of your research work

Submit your manuscript at: http://papersubmission.scirp.org/

Or contactijg@scirp.org 